Abstracta Iranicacta Iranica

Revue bibliographique pour le domaine irano-aryen

Volume 23 | 2002

Comptes rendus des publications de $\mathbf{2 0 0 0}$

\title{
« Zabān-e hāl dar adabiyāt-e fārsī ». Našr-e Dāneš, 17, 2 (1379/2000), pp. 25-42.
}

\section{Charles-Henri de Fouchécour}

\section{(2) OpenEdition}

10 Journals

Édition électronique

URL : http://journals.openedition.org/abstractairanica/35829

DOI : 10.4000/abstractairanica.35829

ISSN : 1961-960X

\section{Éditeur :}

CNRS (UMR 7528 Mondes iraniens et indiens), Éditions de l'IFRI

\section{Édition imprimée}

Date de publication : 15 mai 2002

ISSN : 0240-8910

\section{Référence électronique}

Charles-Henri de Fouchécour, « « Zabān-e hāl dar adabiyāt-e fārsī ». Našr-e Dāneš, 17, 2 (1379/2000), pp. 25-42. », Abstracta Iranica [En ligne], Volume 23 | 2002, document 284, mis en ligne le 08 février 2010, consulté le 25 septembre 2020. URL : http://journals.openedition.org/abstractairanica/35829 ; DOI : https://doi.org/10.4000/abstractairanica.35829

Ce document a été généré automatiquement le 25 septembre 2020.

Tous droits réservés 


\title{
« Zabān-e ḥāl dar adabiyāt-e fārsī ». Našr-e Dāneš, 17, 2 (1379/2000), pp. 25-42.
}

\author{
Charles-Henri de Fouchécour
}

1 Abū Ḥāmed Moḥammad Ġazzālī semble être le premier à avoir parlé, dans l'Ihyya 'ưlūm al-dīn (al-ibāadāt, II, 3, 5), de lisān al-ḥāl (pers. zabān-e ḩāl), en se référant principalement à Coran 17, 46/44, où il est dit qu'il n'est aucune chose au monde qui n'exalte la louange de Dieu. Mais ce langage exprimé par l'état propre à chaque être créé était connu avant Ǵazzālī en littérature persane et fut développé après lui. Ainsi Manūčehrī (ob. 432/1040) dans son exploitation du thème poétique de la vigne et du soleil, ou, dans les quatrains de Hayyām (ob. 517/1123), les paroles que la cruche était supposée avoir tenues au potier, une cruche gūyā-ye Hamūš, parlant muettement. Les récits d'initiation soufis ont tôt usé de ce 'langage d'état' adressé par des êtres inanimés ou animés, pour illustrer une leçon tirée de leur état. Ainsi la meule qui broie le grain enseigne ce qu'est le sama $\bar{a}^{c}$, la danse mystique. Tout autre chose est le récit allégorique, qui est une représentation avec des rôles et une intrigue où les actants, comme la rose et le rossignol, tiennent la place d'actants humains. En fait, l'usage du 'langage par l'état' n'apparaît en mystique qu'avec Sohravardī (ŠeyH al-Ešrāq, ob. 587/1191) dans son traité bien connu sur l'amour (Mūnes al-'oššăq, "Le vade-mecum des fidèles d'amour", traduction d'Henry Corbin, qui note, p. 332, que zabān-e hāl, «c'est laisser parler l'état ou l'aspect sous lequel on se présente, sans prononcer un mot»). A partir de là, la littérature mystique développera ce que Sohravardī a explicitement initié. On le voit par exemple dans le Moșibat-nāme de 'Ațțār, où chaque créature rencontrée, spirituelle ou non, enseigne d'après son état le voyageur en esprit. 'Atțāar s'est fait là très explicite sur ce qu'est ce 'langage selon l'état', par opposition au langage par la parole (zabān-e qāl). 'Ațțār parle aussi de zabān-e fekrat, où fekrat n'est pas ce que conçoivent imagination et raison, mais ce qui est produit par le cœur. On a là toute la différence entre la philosophie rationnelle et les mystères de la Vérité-Réalité. On approche ceuxci non par la raison, mais par le dekr. Ibn 'Arabī (ob. 638/1240) ignorait ce développement de la littérature mystique persane et a connu, sans doute par l'Ihyā de 
Ġazzālī, le thème du lisān al-hāl, qu'il a développé de son côté d'une façon qui lui était propre. Pour lui, c'est le fait même d'exister qui est, pour toute créature, un 'langage d'état' qui professe l'unité-unicité divine et en loue Dieu. Le silence est au contraire le néant. Le 'langage d'état' est plus éloquent que la langue de la parole, puisqu'il est le fait même d'exister. Par son être, tout existant est en état de demande et de louange à l'égard de Dieu. De la sorte, la conception d'Ibn 'Arabī diffère de celle des mystiques persans, car il s'agit pour lui d'un vrai langage objectif, alors que pour eux, il ne s'agit pas d'un langage, mais d'un état dont le poète traduit en langage le sens à l'aide de sa propre imagination, mieux: à l'aide de l'inspiration qu'il éprouve devant cet état. Comme chez Ibn 'Arabī et avant lui, on trouve bien, en littérature persane, l'idée que toute la création est une parole muette de louange à Dieu, et que les hommes ont un langage du cœur et pas seulement de tête et de langue. Le 'langage d'état' est donc, pour les auteurs persans, un procédé narratif qui leur est propre et qu'inspire à leur imagination et à leur cœur le mode d'être des êtres inanimés et animés. C'est par exemple le cas des instruments de musique, comme le roseau bien connu, coupé de sa roselière et qui est censé se plaindre de la séparation. Seul l'amant peut entendre le 'langage d'état' du roseau. L'auteur donne d'autres exemples de ce langage, rencontrés dans la littérature mystique persane, celui de la harpe et du tambour, du luth (dans le Rabāb-nāme de Solțān Valad). Immense sujet, donc, que ce langage muet des êtres à qui le poète donne la parole qu'ils inspirent à son cœur.

INDEX

Thèmes : 11.1.1. Littérature persane classique

\section{AUTEURS}

\section{CHARLES-HENRI DE FOUCHÉCOUR}

Sorbonne Nouvelle - Paris III 